\title{
Determinan struktur modal dan pengaruhnya terhadap return saham pada industri barang dan konsumsi yang terdaftar di BEI
}

\author{
Ega Surya Wulandari, Bambang Sunarko*, \& Tohir \\ Fakultas Ekonomi dan Bisnis, Universitas Jenderal Soedirman, Purwokerto, Indonesia \\ *Email of corresponding author: bambang.sunarko94@yahoo.com
}

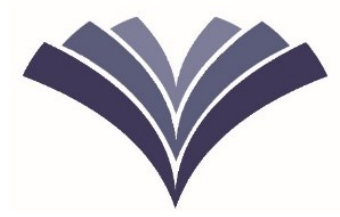

\section{Performance}

Vol. 24 No. 1, 2017

pp. 13-24

Published by Faculty of Economics and Business Jenderal Soedirman

University

on 2 January 2017

DOI:

10.20884/1.performance. 2017.24.1.313

\section{ISSN:}

1829-6467 (Print) 2615-8094 (Online)

How to cite this article: Wulandari, E.S, Sunarko, B. \& Tohir. (2017). Determinan struktur modal dan pengaruhnya terhadap return saham pada industri barang dan konsumsi yang terdaftar di BEI. Performance, 24(1), 13-24.

https://doi.org/10.20884 /1.performance.2017.24.1 .313

This article is available at: http://jos.unsoed.ac.id/in dex.php/performance/art icle/view/313

or scan this with your mobile device

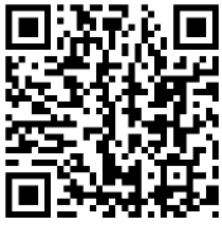

Received 23 November 2016 Revised 7 December 2016 Accepted 21 December 2016

\begin{abstract}
Abstrak
Tujuan: Tujuan penelitian ini adalah untuk menguji pengaruh antara profitabilitas yang diukur menggunakan return on asset (ROA), likuiditas yang diukur menggunakan current ratio (CR), cash holding, non-debt tax shield, dan pertumbuhan aset pada struktur modal yang diukur menggunakan debt to equity ratio (DER), serta pengaruhnya pada return saham.

Metodologi: Penelitian ini dilakukan dari tahun 2011-2015. Penelitian ini menggunakan metode kuantitatif yang memakai studi asosiatif untuk menginvestigasi hubungan antara dua variabel atau lebih. Populasi dari riset ini adalah semua perusahaan yang memproduksi barang konsumsi yang terdaftar di Bursa Efek Indonesia selama periode riset. Penelitian ini mengkombinasikan teknik analisis regresi berganda dan sederhana. Selain itu, pengujian hipotesis dilakukan menggunakan koefisien determinasi, uji statistik F, dan t.

Hasil: Hasil penelitian ini mengindikasikan bahwa profitabilitas (ROA) memiliki pengaruh positif pada struktur modal. Likuiditas (current ratio) dan cash holding memiliki pengaruh negatif pada struktur modal. Non-debt tax shield dan pertumbuhan aset tidak berpengaruh signifikan terhadap struktur modal. Terakhir, struktur modal tidak memiliki pengaruh yang signifikan terhadap return saham.
\end{abstract}

Kata kunci: profitabilitas, likuiditas, cash holding, non-debt-tax shield, pertumbuhan aset, struktur modal, return saham.

\begin{abstract}
Purpose: The purpose of this research is to examine influence between profitability measured by return on asset (ROA), liquidity measured by current ratio (CR), cash holding, non-debt tax shield, and asset growth on capital structure measured by debt to equity ratio (DER) and the influence on stock return.

Methodology: This research was conducted during the period of 2011-2015. This research is quantitative research that used associative studies to determine the relationship or influence between two or more variables. Population in this research was all of consumer goods industries listed on Indonesia Stock Exchange during the period of research. This research combines multiple and simple regression analysis technique. In addition, hypothesis testing used coefficient of determination, $F$-test statistic, and $t$-test statistic.

Findings: The result of this research indicates that profitability (ROA) has positive influence toward capital structure. Liquidity (current ratio) and cash holding have negative influence toward capital structure. Non-debt tax shield and asset growth do not have significant influence toward capital structure. Furthermore, capital structure does not have significant influence toward stock return.

Keywords: profitability, liquidity, cash holding, non-debt-tax shield, asset growth, capital structure, stock return.
\end{abstract}

\section{PENDAHULUAN}

Perkembangan teknologi yang semakin pesat saat ini menciptakan peluang yang besar bagi perusahaan untuk memunculkan banyak inovasi baru yang dapat mempermudah berbagai macam aktivitas kehidupan yang lebih efektif dan efisien. Khususnya pada industri barang dan konsumsi dalam melakukan penyesuaian terhadap keadaan yang terjadi demi memperoleh keunggulan daya saing. Industri barang dan konsumsi merupakan salah satu bagian dari perusahaan manufaktur yang menarik menjadi pilihan untuk investasi. Hal tersebut dikarenakan saham-saham dari industri barang dan konsumsi yang terus menawarkan peningkatan dan sektor industri barang konsumsi berkembang secara bertahap dalam pembangunan dengan menyediakan barang-barang yang dibutuhkan masyarakat terutama pangan, sandang, dan bahan bangunan untuk perumahan. Tersedianya barang-barang tersebut harus diusahakan dalam jumlah yang cukup dengan taraf harga yang berada dalam jangkauan daya beli masyarakat. 
Era globalisasi saat ini, setiap perusahaan dituntut untuk memproduksi barang-barang yang berkualitas demi meningkatkan daya saing di pasaran. Hal tersebut mendorong setiap perusahaan untuk memperoleh dana yang cukup bersaing dan mempertahankan kelangsungan hidup perusahaan. Salah satu cara yang dilakukan oleh perusahaan untuk memperoleh dana adalah dengan menjual saham kepada masyarakat melalui pasar modal. Hal ini dimungkinkan karena pasar modal merupakan wahana yang dapat menggalang pengerahan dana jangka panjang dari masyarakat untuk disalurkan ke sektor-sektor produktif, sehingga dapat beroperasi dengan skala yang lebih besar, misalnya dengan menjual saham di pasar bursa saham atau bursa efek.

Seperti halnya pasar pada umumnya, pasar modal adalah tempat atau sarana bertemunya permintaan dan penawaran atas instrumen keuangan jangka panjang (Samsul, 2008). Instrumen pasar modal yang diterbitkan oleh perusahaan dan dapat digunakan oleh para investor dalam berinvestasi yakni saham. Saham merupakan sertifikat yang menunjukkan kepemilikan suatu perusahaan (Tandelilin, 2010). Keuntungan investasi di pasar modal dapat dicerminkan melalui perolehan return atas saham yang dipilih. Return dapat dikatakan sebagai hasil yang diperoleh dari investasi. Return dapat berupa return realisasi (realized return) yang sudah terjadi atau return ekspektasi (expected return) yang belum terjadi tetapi yang diharapkan akan terjadi di masa mendatang (Jogiyanto, 2010).

Selain menjual saham kepada masyarakat melalui pasar modal dalam mempertahankan kelangsungan hidup perusahaan, perusahaan juga harus mengelola keuangan dengan mempertimbangkan pemenuhan sumber dana. Riyanto (2008) menyatakan bahwa pemenuhan dana tersebut berasal dari sumber intern maupun dari sumber ekstern. Dana yang berasal dari sumber intern adalah dana yang terbentuk atau dihasilkan oleh perusahaan sendiri, yaitu laba ditahan (retained earning) dan depresiasi (depreciation). Sedangkan, dana yang diperoleh dari sumber eksternal adalah dana yang berasal dari kreditur, pemilik, dan pengambil bagian dalam perusahaan. Modal dari kreditur merupakan utang bagi perusahaan yang bersangkutan yang sering disebut sebagai modal asing. Oleh karena itu, setiap manajer keuangan perlu menentukan keputusan struktur modal, yaitu berkaitan dengan penetapan apakah kebutuhan dana perusahaan dipenuhi dengan modal sendiri atau modal asing.

Salah satu bentuk tren pertumbuhan struktur modal pada industri barang dan konsumsi tahun 2011-2015 yaitu terjadinya peningkatan penggunaan hutang dan ekuitas dalam struktur modalnya. Hal ini dapat dilihat pada Gambar 1. Gambar tersebut menunjukkan adanya peningkatan penggunaan ekuitas yang lebih besar dibandingkan dengan penggunaan hutang dari tahun 2011-2015. Peningkatan ini menunjukkan bahwa perusahaan barang dan konsumsi lebih banyak menggunakan ekuitas di bandingkan hutang dalam mendanai operasional perusahaan terhadap permintaan pasar Indonesia yang sedang mengalami peningkatan dalam hal investasi. Hal ini ditopang dari tingginya tingkat konsumsi masyarakat seiring meningkatnya pendapatan kelas menengah dan perubahan gaya hidup. Utamanya, sektor konsumen menawarkan kebutuhan mendasar konsumen, seperti makanan dan minuman.

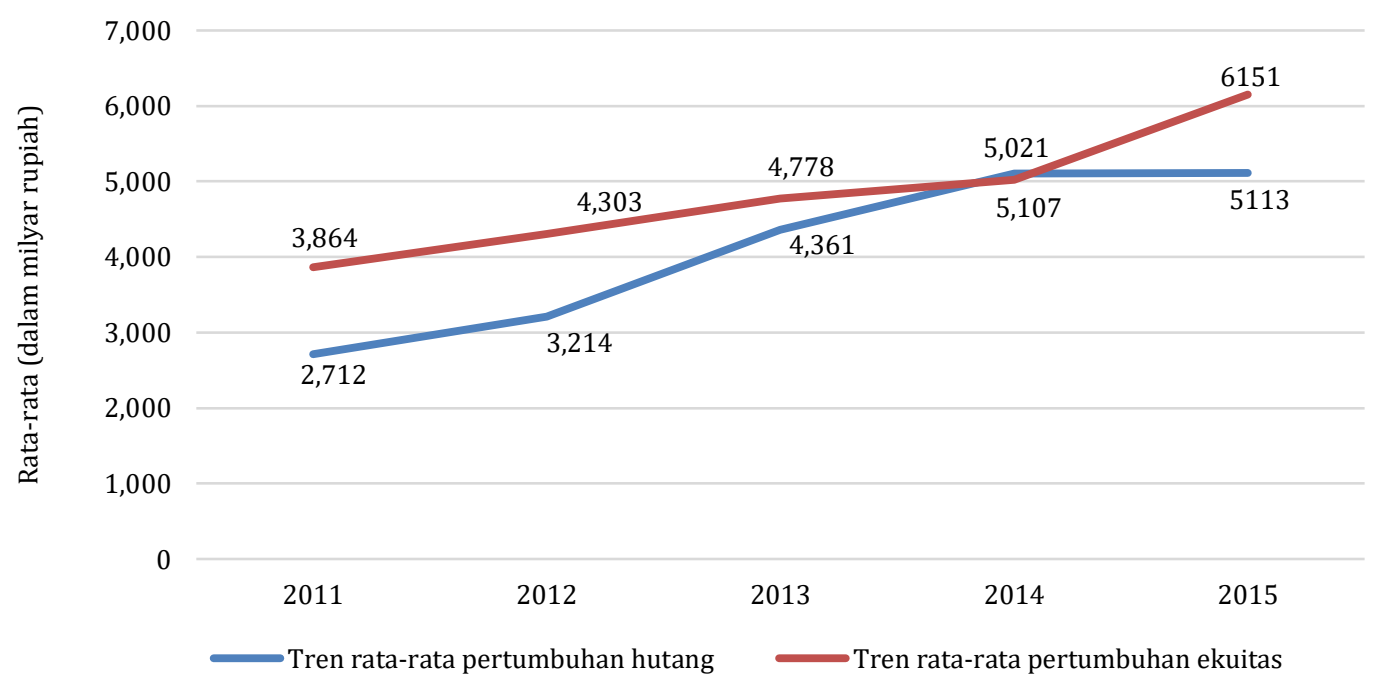

Gambar 1. Tren pertumbuhan struktur modal pada industri barang dan konsumsi

Dalam melakukan keputusan pendanaan, perusahaan juga perlu mempertimbangkan dan menganalisis kombinasi sumber-sumber dana ekonomis guna membelanjai kebutuhan-kebutuhan investasi serta kegiatan usahanya. Kebijakan mengenai struktur modal melibatkan trade off antara risiko dan tingkat pengembalian, 
penambahan utang dapat memperbesar risiko perusahaan, tetapi sekaligus juga memperbesar tingkat pengembalian yang diharapkan. Risiko yang lebih tinggi akibat membesarnya utang cenderung menurunkan harga saham, tetapi meningkatnya pengembalian yang diharapkan akan menaikkan harga saham tersebut. Karena itu, struktur modal yang optimal harus mencapai suatu keseimbangan antara risiko dan pengembalian sehingga dapat memaksimalkan harga saham perusahaan (Brigham dan Houston, 2011). Untuk itu, dalam penetapan struktur modal suatu perusahaan, perlu mempertimbangkan berbagai variabel yang mempengaruhinya.

Faktor-faktor yang mempengaruhi struktur modal menurut Brigham dan Houston (2011) yaitu stabilitas penjualan, struktur aset, tingkat pertumbuhan, profitabilitas, pajak, kendali, sikap manajemen, sikap pemberi pinjaman, kondisi pasar, kondisi internal, dan fleksibilitas keuangan. Sedangkan, menurut Ramlall (2009), faktorfaktor yang mempengaruhi struktur modal seperti growth, size, tangibility of asset, profitability, liquidity, non-debt tax shield, age, dan investment. Dalam penelitian ini, tidak akan dibahas semua faktor yang mempengaruhi keputusan struktur modal perusahaan, hanya beberapa faktor antara lain: profitabilitas, likuiditas, cash holding, non-debt tax shield, dan pertumbuhan perusahaan. Beberapa hasil penelitian terdahulu masih terjadi perbedaan (inkonsistensi) hasil penelitian (research gap) mengenai faktor-faktor yang berpengaruh terhadap struktur modal. Hal tersebut dapat terjadi dimungkinkan karena perbedaan metodologi penelitian, waktu penelitian, ataupun populasi dan sampel yang diteliti. Permasalahan inilah yang akan diangkat menjadi research gap dalam penelitian ini. Dengan demikian, penelitian ini bertujuan menganalisis pengaruh faktor-faktor yang mempengaruhi struktur modal dan pengaruhnya terhadap return saham pada perusahaan industri barang dan konsumsi yang terdaftar di BEI periode 2011-2015.

\section{TINJAUAN PUSTAKA DAN PERUMUSAN HIPOTESIS}

Profitabilitas adalah rasio yang mengukur efektivitas manajemen secara keseluruhan yang ditujukan oleh besar kecilnya tingkat keuntungan yang diperoleh dalam hubungannya dengan penjualan maupun investasi (Fahmi, 2014). Profitabilitas pada perusahaan akan dapat mempengaruhi manajer dalam memberikan keputusan mengenai struktur modal, di mana perusahaan yang memiliki profitabilitas yang tinggi menyebabkan perusahaan akan cenderung memilih pembiayaan operasionalnya dengan modal internal. Hal ini karena pada modal internal dianggap lebih murah dan memiliki tingkat risiko yang rendah dibandingkan dengan menggunakan modal ekternal. Pada penelitian Suwitho dan Zuhro (2016) dan Kristian dan Khuzaini (2014), ditemukan hasil yang menyatakan bahwa variabel profitabiltas mempunyai pengaruh positif terhadap struktur modal. Sedangkan, penelitian Widayanti et al. (2016) menunjukkan hasil yang berkebalikan dengan penelitian sebelumnya yang menyatakan profitabiltas tidak berpengaruh terhadap struktur modal. Penelitian Hasni (2013) dan Yuniati dan Pangestuti (2010) menunjukkan bahwa profitabilitas mempunyai arah pengaruh negatif dan signifikan terhadap struktur modal.

Rasio likuiditas menurut Van Horne dan Wachowicz (2009: 206) adalah rasio yang mengukur kemampuan perusahaan untuk memenuhi kewajiban jangka pendeknya. Pada penelitian Ferdiansya dan Isnurhadi (2013), Yuniati dan Pangestuti (2010), serta Shelly (2016), likuiditas mempunyai pengaruh negatif dan signifikan terhadap struktur modal. Hal tersebut menunjukkan perusahaan yang mempunyai likuiditas yang tinggi akan cenderung tidak menggunakan pembiayaan dari hutang, karena perusahaan dengan tingkat likuiditas tinggi mempunyai dana internal yang besar, sehingga perusahaan tersebut akan lebih menggunakan dana internal terlebih dahulu untuk membiayai investasinya sebelum menggunakan pembiayaan eksternal menggunakan hutang. Namun, Kristian dan Khuzaini (2014) menyatakan bahwa likuiditas berpengaruh positif terhadap struktur modal, di mana semakin tinggi likuiditas suatu perusahaan, maka semakin besar kemampuan perusahaan tersebut untuk membayar kewajiban jangka pendeknya. Hal ini bertentangan dengan Prasojo (2013) yang menyatakan likuiditas tidak berpengaruh terhadap struktur modal.

Menurut Martono dan Harjito (2010), cash holding merupakan salah satu bagian dari aktiva yang memiliki sifat paling lancar (paling likuid) dan paling mudah berpindah tangan dalam suatu transaksi. Transaksi tersebut misalnya untuk pembayaran gaji atau upah pekerja, membeli aktiva tetap, membayar hutang, membayar dividen, dan transaksi lain yang diperlukan perusahaan. Penelitian yang dilakukan oleh Sulistyowati (2009) dan Yuniati dan Pangestuti (2010) menunjukkan bahwa cash holding berpengaruh negatif terhadap struktur modal yang mengindikasikan jika cash holding meningkat, maka perusahaan tersebut cenderung mempunyai tingkat hutang yang rendah karena perusahaan lebih memilih mendanai kebutuhan dananya dari pendanaan internal. Pendanaan internal lebih dulu dilakukan karena perusahaan memiliki uang kas dan deposito yang cukup untuk mendanai kebutuhan operasional, sehingga kemungkinan besar perusahaan cenderung tidak menggunakan hutang. 
Non-debt tax shield (NDTS) atau penghematan pajak yang bukan bersumber dari utang merupakan penghematan pajak yang bukan berasal dari bunga pinjaman yang dibayarkan. (Krisnanda dan Wiksuana, 2015). Non-debt tax shield tersebut berupa depresiasi aktiva tetap. Semakin tinggi depresiasi suatu perusahaan, maka semakin tinggi aktiva tetap yang dimiliki perusahaan, sehingga perusahaan akan lebih mudah mendapatkan utang dari pihak luar dengan menjaminkan aset dari perusahaan. Penelitian yang dilakukan oleh Krisnanda dan Wiksuana (2015) menemukan bahwa variabel non-debt tax shield (penghematan pajak) berpengaruh positif dan signifikan terhadap struktur modal. Nurita dan Mawardi (2012) menyatakan bahwa non-debt tax shield ternyata mempunyai arah pengaruh negatif dan signifikan terhadap struktur modal. Sedangkan, penelitian yang dilakukan oleh Stella (2015) dan Margaretha dan Ramadhan (2010) menyatakan bahwa non-debt tax shield tidak berpengaruh terhadap struktur modal.

Pertumbuhan perusahaan merupakan indikator untuk menilai prospek perusahaan di masa mendatang dengan mengukur perubahan total aset. Perusahaan yang aktivanya terus meningkat mengindikasikan perusahaan sedang dalam tahap ekspansi. Tentu saja, perusahaan yang sedang tumbuh memerlukan dana yang besar, sehingga terkadang perlu mengambil pendanaan eksternal berupa utang. Hal ini sesuai dengan penelitian yang dilakukan oleh Khariry dan Yusniar (2016) dan Margaretha dan Ramadhan (2010) bahwa pertumbuhan perusahaan berpengaruh positif dan signifikan terhadap struktur modal. Sedangkan, pada penelitian yang dilakukan oleh Febriyani dan Srimindarti (2010), pertumbuhan perusahaan dinyatakan berpengaruh negatif dan tidak signifikan terhadap struktur modal. Hasil yang bertentangan yang menyatakan bahwa pertumbuhan perusahaan tidak berpengaruh terhadap struktur modal disampaikan oleh Nurmadi (2013) dan Yushinta dan Erni (2010). Berdasarkan uraian di atas, hipotesis dalam penelitian ini di rumuskan sebagai berikut:

$\mathrm{H}_{1}$ : Return on asset berpengaruh negatif terhadap debt to equity ratio.

$\mathrm{H}_{2}$ : Current ratio berpengaruh negatif terhadap debt to equity ratio.

$\mathrm{H}_{3}$ : Cash holding berpengaruh negatif terhadap debt to equity ratio.

$\mathrm{H}_{4}$ : Non-debt tax shield berpengaruh negatif terhadap debt to equity ratio.

$\mathrm{H}_{5}$ : Pertumbuhan aset berpengaruh positif terhadap debt to equity ratio.

$\mathrm{H}_{6}$ : Debt to equity ratio berpengaruh negatif terhadap return saham.

\section{METODE PENELITIAN}

\section{Populasi dan sampel penelitian}

Jenis data dalam penelitian ini adalah data sekunder, yaitu data yang diperoleh secara tidak langsung dari perusahaan, melainkan dari pihak ketiga, yaitu situs resmi Bursa Efek Indonesia (www.idx.co.id). Pemilihan sampel penelitian ini ditentukan dengan teknik pengambilan purposive sampling, yaitu teknik penentuan sampel dengan pertimbangan tertentu (Sugiyono, 2012). Adapun kriteria yang digunakan dalam menentukan sampel adalah: (1) industri barang dan konsumsi yang terdaftar di Bursa Efek Indonesia dan tidak delist (keluar) selama periode penelitian dari tahun 2011-2015 dan (2) industri barang dan konsumsi yang terdaftar di Bursa Efek Indonesia yang memiliki data laporan keuangan tahun 2011-2015 sesuai variabel-variabel yang diteliti (return on asset, current ratio, cash holding, non-debt tax shield, asset growth, debt to equity ratio, dan return saham). Berdasarkan kriteria di atas, diperoleh sampel penelitian sebanyak 21 perusahaan. Sehingga, data observasi dalam penelitian ini sebanyak 105 data (21 perusahaan $\mathrm{x} 5$ tahun).

\section{Variabel penelitian}

Return saham diukur dengan actual return, yakni selisih antara harga saham periode sekarang dengan harga saham periode sebelumnya dibagi harga saham pada periode sebelumnya atau dapat juga dinyatakan sebagai berikut (Tandelilin, 2010):

$$
\mathrm{R}_{\mathrm{t}}=\frac{\mathrm{P}_{\mathrm{t}}-\mathrm{P}_{\mathrm{t}-1}}{\mathrm{P}_{\mathrm{t}-1}}
$$

Keterangan :

$\mathrm{R}_{\mathrm{t}} \quad:$ Return saham pada periode ke- $\mathrm{t}$

$P_{t} \quad$ : Harga saham pada periode $t$

$\mathrm{P}_{(\mathrm{t}-1)}$ : Harga saham periode sebelum $\mathrm{t}$ 
Pada penelitian ini, struktur modal diproksikan dengan debt to equity ratio (DER). Rasio DER digunakan untuk mengukur kemampuan perusahaan membayar hutang-hutang yang dimilikinya dengan modal atau ekuitas yang ada (Najmudin, 2011).

$$
\text { DER }=\frac{\text { Total debt }}{\text { Total equity }}
$$

Analisis ROA (return on asset) mengukur kemampuan perusahaan menghasilkan laba dengan menggunakan total aset (kekayaan) yang dipunyai perusahaan setelah disesuaikan dengan biaya-biaya untuk mendanai dana tersebut (Hanafi dan Halim, 2012).

$$
\mathrm{ROA}=\frac{\text { Earning after tax }}{\text { Total asset }}
$$

Current ratio merupakan perbandingan antara aktiva lancar (current asset) dengan hutang lancar (current liability). Aktiva lancar terdiri dari kas, surat-surat berharga, piutang, dan persediaan. Sedangkan hutang lancar terdiri dari hutang dagang, hutang wesel, hutang pajak, hutang gaji/upah, dan hutang jangka pendek lainnya (Martono dan Harjito, 2010).

$$
\text { Current ratio }=\frac{\text { Current asset }}{\text { Current liability }}
$$

Cash holding didefinisikan sebagai kas yang dimiliki perusahaan yang sifatnya jangka pendek. Kas adalah uang tunai yang digunakan untuk membiayai operasi perusahaan. Berdasarkan Mohammadi et al. (2012), cash holding diukur dengan menjumlahkan kas dan setara kas dibagi total aset, atau dapat dirumuskan sebagai berikut:

$$
\text { Current holding }=\frac{\text { Cash }+ \text { Cash equivalent }}{\text { Total asset }}
$$

Adhegaonkar dan Indi (2012) mengungkapkan bahwa non-debt tax shield dapat berasal dari depresiasi atau biaya penyusutan yang merupakan pengganti terbaik atas bunga pinjaman dalam hal perlindungan pajak. Nondebt tax shield merupakan rasio penyusutan terhadap total aktiva atau perkiraan langsung total aktiva. Non-debt tax shield dapat diformulasikan sebagai berikut:

$$
\text { NDTS }=\frac{\text { Depreciation }}{\text { Total asset }}
$$

Pengukuran pertumbuhan (growth) aset dapat diukur dengan membandingkan antara total aktiva tahun yang bersangkutan (tahun ke-t) dikurangi jumlah total tahun sebelumnya (tahun ke t-1) kemudian dibagi dengan jumlah total tahun sebelumnya (tahun ke t-1). Berikut ini adalah formulanya:

$$
\text { Asset growth }=\frac{\mathrm{TA}_{\mathrm{t}}-\mathrm{TA}_{\mathrm{t}-1}}{\mathrm{TA}_{\mathrm{t}-1}}
$$

Keterangan :

$\mathrm{TA}_{\mathrm{t}} \quad$ : Total aktiva pada periode $\mathrm{t}$

$\mathrm{TA}_{\mathrm{t}-1}$ : Total aktiva sebelum periode $\mathrm{t}$

\section{Teknik analisis data}

Analisis data pada penelitian ini menggunakan analisis asosiatif berupa regresi berganda dan regresi sederhana dengan uji asumsi klasik menggunakan uji normalitas, uji multikolinieritas, uji heteroskedastisitas, dan uji autokorelasi menggunakan SPSS 17 (Suliyanto, 2011). 


\section{HASIL}

\section{Analisis deskriptif}

Tabel 1. Analisis statistik deskriptif

\begin{tabular}{lccccc}
\hline & \multicolumn{4}{c}{ Descriptive statistic } \\
\cline { 2 - 5 } & $\mathrm{N}$ & Min & Max & Mean & Std. deviation \\
\hline ROA & 105 & $-0,04$ & 0,43 & 0,1321 & 0,11044 \\
Current ratio & 105 & 0,64 & 11,74 & 2,8374 & 1,87009 \\
Cash holding & 105 & 0,00 & 0,50 & 0,1445 & 0,12403 \\
NDTS & 105 & 0,00 & 1,82 & 0,2347 & 0,19807 \\
Asset growth & 105 & $-0,09$ & 0,59 & 0,1329 & 0,13137 \\
DER & 105 & 0,11 & 2,26 & 0,7484 & 0,48883 \\
Return saham & 105 & $-0,99$ & 2,38 & 0,1426 & 0,49572 \\
\hline Valid N (listwise) & 105 & \multicolumn{4}{c}{} \\
\hline
\end{tabular}

Berdasarkan Tabel 1, diperoleh hasil statistik deskriptif dari keenam variabel yang digunakan dalam penelitian dan diketahui bahwa semua variabel memiliki jumlah data $(\mathrm{N})$ sebanyak 105. Jumlah tersebut diperoleh dari sampel perusahaan sebanyak 21 perusahaan, kemudian dikalikan dengan periode pengamatan selama lima tahun. Dari sampel perusahaan, diketahui bahwa variabel profitabilitas (ROA) mempunyai mean sebesar 0,1321 dengan standar deviasi sebesar 0,11044. Perusahaan yang memiliki return on asset tertinggi adalah Unilever Indonesia, Tbk. pada tahun 2014 yaitu sebesar 0,43, sedangkan perusahaan yang memiliki return on asset terendah adalah Indofarma, Tbk. pada tahun 2013 sebesar -0,04. Variabel likuiditas (current ratio) mempunyai mean sebesar 2,8374 dengan standar deviasi sebesar 1,87009. Perusahaan yang memiliki current ratio tertinggi adalah Mandom Indonesia, Tbk. pada tahun 2011 yaitu sebesar 11,74, sedangkan perusahaan yang memiliki current ratio terendah adalah Unilever Indonesia, Tbk. pada tahun 2012 sebesar 0,64.

Variabel cash holding mempunyai mean sebesar 0,1445 dengan standar deviasi sebesar 0,12403. Perusahaan yang memiliki cash holding tertinggi adalah Delta Djakarta, Tbk. pada tahun 2013 yaitu sebesar 0,50, sedangkan perusahaan yang memiliki cash holding terendah adalah H. M. Sampoerna, Tbk. pada tahun 2014 sebesar 0,00. Variabel non-debt tax shield mempunyai mean sebesar 0,2347 dengan standar deviasi sebesar 0,19807. Perusahaan yang memiliki non-debt tax shield tertinggi adalah Kedaung Indah Can, Tbk. pada tahun 2015 yaitu sebesar 1,82, sedangkan perusahaan yang memiliki non-debt tax shield terendah adalah Ultra Jaya Milk Industry and Trading Company, Tbk. pada tahun 2011 sebesar 0,00.

Variabel asset growth mempunyai mean sebesar 0,1329 dengan standar deviasi sebesar 0,13137. Perusahaan yang memiliki asset growth tertinggi adalah Nippon Indosari Corpindo, Tbk. pada tahun 2012 yaitu sebesar 0,59, sedangkan perusahaan yang memiliki asset growth terendah adalah Merck Indonesia, Tbk. pada tahun 2015 sebesar -0,09. Variabel struktur modal (DER) mempunyai mean sebesar 0,7484 dengan standar deviasi sebesar 0,48883. Perusahaan yang memiliki debt to equity ratio tertinggi adalah Unilever Indonesia, Tbk. pada tahun 2015 yaitu sebesar 2,26, sedangkan perusahaan yang memiliki debt to equity ratio terendah adalah Mandom Indonesia, Tbk. pada tahun 2011 sebesar 0,11. Variabel return saham mempunyai mean sebesar 0,1426 dengan standar deviasi sebesar 0,49572. Perusahaan yang memiliki return saham tertinggi adalah Ultra Jaya Milk Industry and Trading Company, Tbk. pada tahun 2013 yaitu sebesar 2,38, sedangkan perusahaan yang memiliki return saham terendah adalah Delta Djakarta, Tbk. pada tahun 2015 sebesar -0,99.

\section{Uji asumsi klasik}

Uji normalitas dimaksudkan untuk menguji apakah nilai residual yang telah distandarisasi pada model regresi berdistribusi normal atau tidak. Berdasarkan output dari SPSS, nilai Sig. (2-tailed) sebesar 0,093 >0,05. Hal ini berarti residual terstandarisasi dinyatakan menyebar secara normal. Sedangkan, hasil uji normalitas variabel $Y_{1}$ terhadap $Y_{2}$ menunjukkan bahwa nilai Sig. (2-tailed) sebesar 0,61 $>0,05$. Hal ini berarti residual terstandarisasi dinyatakan menyebar secara normal. Uji multikolinieritas bertujuan untuk menguji apakah dalam model regresi yang terbentuk ada korelasi yang tinggi atau sempurna di antara variabel bebas atau tidak. Uji multikolinieritas dilakukan dengan melihat nilai variance inflation factor (VIF) dari masing-masing variabel bebas terhadap variabel terikat. Dengan melihat VIF variabel profitabilitas sebesar 1,052, likuidias sebesar 1,387, cash holding sebesar 1,356, non-debt tax shield sebesar 1,238, dan pertumbuhan perusahaan sebesar 1,009 di mana masing- 
masing dari nilai tersebut kurang dari 10, maka pada model regresi yang terbentuk tidak terjadi gejala multikolinier.

Uji heteroskedasitatisitas terjadi apabila ada varian variabel pada model regresi yang tidak sama (konstan). Uji heteroskedasitas pada penelitian ini dengan menggunakan uji Park. Berdasarkan output SPSS, diketahui bahwa model regresi tidak terjadi heteroskedastisitas. Hal ini karena Sig. variabel ROA sebesar 0,131, current ratio sebesar 0,933, cash holding sebesar 0,083, non-debt tax shield sebesar 0,174, dan asset growth sebesar 0,574 terhadap $\mathrm{LnU}_{2}>0,05$. Sedangkan, diketahui bahwa model regresi tidak terjadi heteroskedastisitas. Hal ini karena Sig. variabel struktur modal sebesar 0,507 $>0,05$.

Uji autokorelasi bertujuan untuk mengetahui apakah ada korelasi antara anggota serangkaian data observasi yang diuraikan meneurut waktu (time series) atau ruang (cross section). Dalam penelitian ini, uji autokorelasi yang digunakan adalah metode Lagrange Multiplier (LM test). Ketentuan penarikan kesimpulan adalah dengan membandingkan $\chi^{2}$ hitung dengan $\chi^{2}$ tabel dengan $\mathrm{df}=(\alpha, \mathrm{n}-1)$. Jika nilai $\chi^{2}$ hitung $>\chi^{2}$ tabel, maka terdapat masalah autokorelasi. Sebaliknya, jika $\chi^{2}$ hitung $\leq \chi^{2}$ tabel, maka tidak terjadi masalah auto korelasi. Nilai $\mathrm{R}^{2}$ ini digunakan sebagai dasar untuk menghitung $\chi^{2}$ hitung dengan rumus $\chi^{2}=(n-1) \times R^{2}$. Dengan nilai $R^{2}$ sebesar 0,348 dan jumlah pengamatan sebanyak 105 , maka $\chi^{2}$ hitung sebesar: (105-1) x 0,348 $=36,192$. Sedangkan, nilai $\chi^{2}$ tabel dengan $\mathrm{df}=(0,05 ; 104)$ sebesar 128,8039 . Karena nilai $\chi^{2}$ hitung $(36,192) \leq \chi^{2}$ tabel $(128,8039)$, maka persamaan regresi tidak mengandung masalah autokorelasi.

\section{Persamaan regresi linier}

Persamaan regresi linier berganda sebagai berikut:

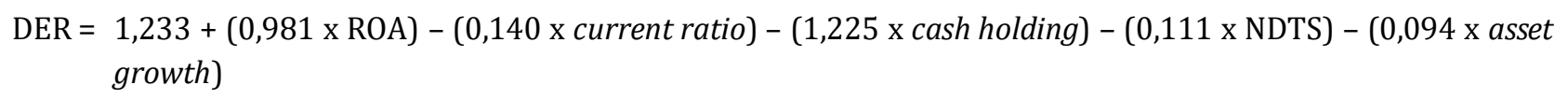

Sedangkan persamaan regresi linier sederhananya adalah sebagai berikut:

Return saham $=0,190-(0,064 \times$ DER $)$

\section{Pengujian model statistik}

Pengujian ini dilakukan untuk mengetahui hubungan antara variabel independen (return on asset, current ratio, cash holding, non-debt tax shield, dan asset growth) dan variabel dependen (debt to equity ratio). Hasil analisis untuk nilai $\mathrm{R}^{2}$ pada analisis regresi linier berganda sebesar 0,518 . Hal ini menunjukkan bahwa perubahan variabel debt to equity ratio dijelaskan oleh variabel independen yaitu return on asset, current ratio, cash holding, non-debt tax shield, dan asset growth sebesar 51,8 persen. Sedangkan, sisanya sebesar 48,2 persen dijelaskan oleh variabelvariabel lain yang tidak diteliti. Hasil analisis untuk nilai $\mathrm{R}^{2}$ pada analisis regresi sederhana sebesar 0,004 . Hal ini menunjukkan bahwa perubahan variabel return saham dijelaskan oleh variabel independen yaitu debt to equity ratio sebesar 0,4 persen. Sedangkan, sisanya sebesar 99,6 persen dijelaskan oleh variabel-variabel lain yang tidak diteliti.

\section{Uji signifikansi simultan (uji $\mathbf{F}_{\text {statistik}}$ )}

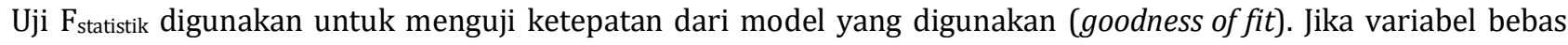
memiliki pengaruh secara simultan terhadap variabel tergantung, maka model persamaan regresi masuk dalam kriteria cocok atau fit. Dengan nilai $\mathrm{F}_{\text {tabel }}$ sebesar 2,306 dengan $\mathrm{df}=\alpha,(\mathrm{k}-1),(\mathrm{n}-\mathrm{k})$ dengan tingkat keyakinan $(\alpha)$ sebesar 0,05. Karena nilai $\mathrm{F}_{\text {hitung }}>\mathrm{F}_{\text {tabel }}(21,284>2,306)$, maka dapat disimpulkan bahwa variabel return on asset, current ratio, cash holding, non-debt tax shield, dan asset growth secara bersama-sama (simultan) berpengaruh signifikan terhadap debt to equity ratio dan persamaan regresi dinyatakan baik (goodness of fit).

\section{PeMbahasan}

\section{Return on asset}

Hasil penelitian menunjukkan bahwa nilai t-hitung variabel ROA sebesar 3,098, dimana thitung $(3,098)>t_{\text {tabel }}(-$ $1,66039)$ dengan tingkat signifikansi $(0,003)<\alpha(0,05)$, maka secara parsial ROA berpengaruh positif signifikan terhadap DER. Sehingga, hipotesis pertama $\left(\mathrm{H}_{1}\right)$ yang menyebutkan bahwa ROA berpengaruh negatif terhadap DER ditolak. 
Hasil dalam penelitian ini menunjukan bahwa ROA memiliki hubungan positif dan signifikan terhadap DER sehingga hipotesis dalam penelitian ini yang menyatakan ROA berpengaruh negatif terhadap DER ditolak. Data yang diperoleh dalam penilitian ini menunjukkan jika industri barang dan konsumsi yang terdaftar di Bursa Efek Indonesia yang menginginkan struktur modalnya dalam kondisi yang optimal, harus mempertimbangkan besaran laba yang dihitung melalui return on asset. Dilihat dari teori keagenan, maka hubungan positif antara profitabilitas dengan struktur modal menunjukkan bahwa investor menghendaki adanya hutang agar ada yang mengontrol manajemen perusahaan. Perusahaan yang memiliki profitabilitas tinggi menghindarkan perusahaan dari kebangkrutan dan diharapkan memiliki kesempatan investasi yang lebih baik. Hal ini membuat para investor atau kreditor lebih yakin dalam memberikan hutangnya kepada perusahaan, sehingga hubungan antara profitabilitas dengan struktur modal adalah positif.

Semakin tinggi tingkat ROA perusahaan barang dan konsumsi, maka akan semakin meningkatkan tingkat kepercayaan pihak eksternal (kreditor) untuk meminjamkan dananya kepada perusahaan. Semakin meningkatnya tingkat kepercayaan kreditor, maka akan memudahkan perusahaan dalam mendapatkan hutang, singkatnya akan meningkatkan DER dari perusahaan yang bersangkutan. Hasil ini sesuai dengan penelitian Suwitho dan Zuhro (2016) dan Kristian dan Khuzaini (2014) yang menunjukan hasil bahwa variabel profitabilitas mempunyai pengaruh positif dan signifikan terhadap struktur modal. Namun hasil penelitian ini tidak sejalan dengan penelitian yang dilakukan oleh Hasni (2013) dan Yuniati dan Pangestuti (2010) bahwa ROA mempunyai pengaruh negatif terhadap DER. Perusahaan dengan tingkat pengembalian atau profitabilitas ROA yang tinggi cenderung menggunakan dana sendiri atau laba ditahan melanjutkan operasional perusahaan tersebut. Karena pendanaan yang berasal dari dalam perusahaan memiliki resiko yang rendah. Selain itu, perusahaan tersebut terbilang masih mampu untuk membiayai usahanya melalui laba ditahan, tidak memerlukan adanya hutang.

\section{Current ratio}

Hasil penelitian menunjukkan bahwa nilai thitung variabel current ratio sebesar $-6,540$, di mana $t_{\text {hitung }}(-6,540)>t_{\text {tabel }}$ $(-1,66039)$ dengan tingkat signifikansi $(0,000)<\alpha(0,05)$, maka secara parsial current ratio berpengaruh negatif signifikan terhadap DER. Sehingga, hipotesis kedua $\left(\mathrm{H}_{2}\right)$ yang menyebutkan bahwa current ratio berpengaruh negatif terhadap DER diterima. Hasil dalam penelitian ini menunjukan bahwa current ratio memiliki hubungan negatif dan signifikan terhadap DER, sehingga hipotesis dalam penelitian ini yang menyatakan current ratio berpengaruh negatif terhadap DER diterima. Hal tersebut menunjukan rasio likuiditas yang tinggi dapat dipertimbangkan oleh investor untuk menjadi sinyal yang positif yang mengindikasikan bahwa perusahaan dapat memenuhi kewajiban lancarnya dan dihadapkan pada risiko kebangkrutan yang rendah.

Posisi likuiditas perusahaan yang tinggi menunjukkan kemampuan perusahaan memenuhi kewajiban jangka pendeknya, dengan laba ditahan yang besar, perusahaan akan lebih senang menggunakan laba ditahan untuk operasi perusahaan sebelum menggunakan hutang atau menerbitkan saham baru. Laba yang tidak dibagikan sebagai dividen akan dipergunakan untuk ekspansi yang biasanya berarti pembelian aset. Hal ini sesuai dengan pecking order theory yang mengatakan bahwa manajer lebih senang menggunakan pembiayaan dengan urutan pertama laba ditahan, kemudian hutang, dan terakhir penjualan saham baru. Pertimbangan lain karena biaya langsung untuk pembiayaan dari dalam yaitu laba ditahan lebih murah dibandingkan dengan biaya modal yang berasal dari penerbitan emisi saham baru. Hasil ini sejalan dengan penelitian Ferdiansya dan Isnurhadi (2013), Yuniati dan Pangestuti (2010), serta Shelly (2016) bahwa likuiditas mempunyai pengaruh negatif dan signifikan terhadap struktur modal. Namun, hasil penelitian ini bertentangan dengan Prasojo (2013) yang menyatakan likuiditas tidak berpengaruh terhadap struktur modal.

\section{Cash holding}

Hasil penelitian menunjukkan bahwa nilai thitung variabel cash holding sebesar $-3,825$, di mana thitung $(-3,825)>$ tabel $(-1,66039)$ dengan tingkat signifikansi $(0,000)<\alpha(0,05)$, maka secara parsial cash holding berpengaruh negatif signifikan terhadap DER. Sehingga, hipotesis ketiga $\left(\mathrm{H}_{3}\right)$ yang menyebutkan bahwa cash holding berpengaruh negatif terhadap DER diterima. Hasil dalam penelitian ini menunjukan bahwa cash holding memiliki hubungan negatif dan signifikan terhadap DER, sehingga hipotesis dalam penelitian ini yang menyatakan cash holding berpengaruh negatif terhadap DER diterima. Hal tersebut mengindikasikan jika cash holding meningkat, maka perusahaan tersebut cenderung mempunyai tingkat hutang yang rendah, karena perusahaan lebih memilih mendanai kebutuhan dananya dari pendanaan internal. Pendanaan internal lebih dulu dilakukan karena perusahaan memiliki uang kas yang cukup untuk mendanai kebutuhan operasional, sehingga kemungkinan besar 
perusahaan cenderung tidak menggunakan hutang. Perusahaan juga harus dapat menjaga kas yang dimiliki pada tingkat yang optimal, karena menahan kas terlalu besar dalam aktiva adalah hal yang tidak produktif. Salah satu tujuan perusahaan memiliki cash holding antara lain untuk membayar hutang, membiayai kesempatan investasi yang menguntungkan, serta sebagai cadangan apabila terdapat kejadian-kejadian yang tidak terduga di masa yang akan datang. Menurut pecking order theory, perusahaan yang mempunyai cash holding tinggi akan cenderung tidak menggunakan pembiayaan dari hutang. Hasil ini sejalan dengan penelitian yang dilakukan oleh Sulistyowati (2009) dan Yuniati dan Pangestuti (2010) bahwa cash holding berpengaruh negatif terhadap struktur modal.

\section{Non-debt tax shield}

Hasil penelitian menunjukkan bahwa nilai thitung variabel non-debt tax shield sebesar $-0,577$, di mana thitung $(-0,577)$ $<$ tabel $(-1,66039)$ dengan tingkat signifikansi $(0,565)>\alpha(0,05)$, maka secara parsial non-debt tax shield tidak berpengaruh negatif signifikan terhadap DER. Sehingga, hipotesis keempat $\left(\mathrm{H}_{4}\right)$ yang menyebutkan bahwa nondebt tax shield berpengaruh negatif terhadap DER ditolak. Hasil dalam penelitian ini menunjukan bahwa non-debt tax shield memiliki hubungan negatif dan tidak signifikan terhadap DER, sehingga hipotesis dalam penelitian ini yang menyatakan non-debt tax shield berpengaruh negatif terhadap DER ditolak. Hasil ini menunjukkan bahwa depresiasi tidak mempengaruhi utang yang artinya bahwa utang tersebut tidak digunakan untuk mendanai investasi dalam bentuk aktiva tetap, akan tetapi utang tersebut digunakan oleh perusahaan untuk mendanai operasional perusahaan sebagai modal kerja.

Penghematan pajak yang bukan bersumber dari utang memiliki hubungan negatif tidak signifikan. Arah hubungan negatif ini bermakna bahwa semakin besar penghematan pajak yang bukan bersumber dari utang akan diikuti dengan penurunan utang. Penjelasan dari hasil ini adalah dengan adanya aturan perpajakan yang ketat mengenai metode penyusutan yang diperkenankan dalam penghitungan pajak, maka penghematan pajak yang bukan bersumber dari utang tidak berpengaruh terhadap besarnya utang yang akan digunakan perusahaan. Hal ini berarti keuntungan dari hutang adalah bunga hutang dapat sebagai pengurangan pajak, karena pembayaran bunga tersebut dimasukkan sebagai beban didalam perhitungan pajak, biaya bunga hutang yang dapat mengurangi pajak tersebut yang sering disebut sebagai perlindungan pajak. Oleh karena itu, perusahaan lebih besar menggunakan tingkat hutang pada struktur modalnya untuk mendapatkan benefit dari tax shield. Hasil penelitian ini sejalan dengan penelitian Stella (2015) dan Margaretha dan Ramadhan (2010) bahwa non-debt tax shield tidak berpengaruh terhadap DER. Namun, tidak sejalan dengan hasil penelitian yang dilakukan oleh Nurita dan Mawardi (2012) bahwa non-debt tax shield mempunyai pengaruh negatif terhadap DER. Non-debt tax shield pada penelitian ini menggunakan item depresiasi. Dengan depresiasi yang tinggi berarti dapat dikatakan bahwa perusahaan mempunyai investasi dalam bentuk aktiva tetap yang tinggi. Semakin meningkatnya depresiasi, maka berarti bertambah juga jumlah aktiva tetap yang diinvestasikan disuatu perusahaan dan akan berakibat terhadap besarnya jumlah aktiva yang dimiliki perusahaan, sehingga akan menurunkan hutang.

\section{Asset growth}

Hasil penelitian menunjukkan bahwa nilai t-hitung variabel asset growth sebesar $-0,360$, di mana $t_{\text {hitung }}(-0,360)<$ $t_{\text {tabel }}(1,66039)$ dengan tingkat signifikansi $(0,720)>\alpha(0,05)$, maka secara parsial asset growth tidak berpengaruh negatif signifikan terhadap DER. Sehingga, hipotesis kelima $\left(\mathrm{H}_{5}\right)$ yang menyebutkan bahwa asset growth berpengaruh positif terhadap DER ditolak. Hasil dalam penelitian ini menunjukan bahwa asset growth memiliki hubungan negatif dan tidak signifikan terhadap DER, sehingga hipotesis dalam penelitian ini yang menyatakan asset growth berpengaruh positif terhadap DER ditolak. Dalam pecking order theory disebutkan bahwa semakin tinggi tingkat pertumbuhan perusahaaan menyebabkan semakin besar kebutuhan dana yang diperlukan untuk melakukan ekspansi. Pemenuhan kebutuhan dana perusahaan dipenuhi dengan penggunaan sumber dana internal perusahaan. Perusahaan dengan tingkat pertumbuhan tinggi berusaha memenuhi kebutuhan dananya dengan menggunakan sumber dana internal perusahaan. Pemegang saham perusahaan yang mengalami tingkat pertumbuhan yang tinggi tidak ingin kesempatan untuk mendapatkan laba dari perusahaan yang memiliki peluang pertumbuhan baik. Sehingga, pemenuhan kebutuhan dana tersebut akan lebih diutamakan melalui sumber dana internal perusahaan. Hasil ini sejalan dengan penelitian oleh Nurmadi (2013) dan Yushinta dan Erni (2010) bahwa pertumbuhan aset tidak berpengaruh terhadap struktur modal. Namun, tidak sejalan dengan hasil penelitian yang dilakukan oleh Khariry dan Yusniar (2016) dan Margaretha dan Ramadhan (2010) bahwa pertumbuhan aset berpengaruh positif terhadap DER. Perusahaan dengan tingkat pertumbuhan yang tinggi cenderung lebih banyak menggunakan hutang (obligasi) dibanding perusahaan yang lambat pertumbuhanya. 
Pada perusahaan dengan tingkat pertumbuhan rendah, kebutuhan modal baru relatif kecil, sehingga dapat dipenuhi dari laba ditahan.

\section{Debt to equity ratio}

Hasil penelitian menunjukkan bahwa nilai t-hitung variabel DER sebesar $-0,639$, di mana thitung $(-0,639)<t_{\text {tabel }}(-$ 1,65978) dengan tingkat signifikansi $(0,525)>\alpha(0,05)$, maka secara parsial DER tidak berpengaruh negatif signifikan terhadap return saham. Sehingga, hipotesis keenam $\left(\mathrm{H}_{6}\right)$ yang menyebutkan bahwa DER berpengaruh negatif terhadap return saham ditolak. Hasil dalam penelitian ini menunjukan bahwa DER memiliki hubungan negatif dan tidak signifikan terhadap return saham, sehingga hipotesis dalam penelitian ini yang menyatakan DER berpengaruh negatif terhadap return saham ditolak. Hubungan negatif ini mengindikasikan bahwa ada pandangan yang berbeda mengenai nilai DER. Beberapa investor berpikir bahwa semakin tinggi DER, maka akan semakin tinggi hutang perusahaan, sehingga meningkatkan risiko yang diterima investor sebagai akibat dari beban bunga hutang yang ditanggung perusahaan. Hal tersebut menyebabkan investor cenderung untuk tidak menanamkan modalnya pada perusahaan, sehingga terjadi penurunan harga saham yang selanjutnya berdampak terhadap turunnya return saham perusahaan.

Hasil penelititan ini tidak signifikan karena pada industri barang dan konsumsi yang diteliti saat ini menunjukan bahwa penggunaan hutang perusahaan tidak mempengaruhi return saham, hal ini dapat terjadi karena secara umum bukanlah proporsi hutang yang menentukan keputusan investor dalam menanamkan modalnya, melainkan dengan melihat aspek-aspek fundamental dari perusahaan yang memasuki pasar modal seperti profitabilitas atau laba perusahaan itu sendiri. Jadi, ada penilaian yang berbeda dari investor terhadap arti pentingnya hutang bagi perusahaan. Hasil dari return saham pada perusahaan ini juga tidak konstan yang mengakibatkan banyak nilai negatif, hal ini karena pada harga saham penutupan mengabaikan adanya corporate action, yaitu stock split. DER memiliki hubungan negatif dan tidak signifikan terhadap return saham. Namun bertentangan dengan hasil penelitian yang dilakukan oleh Arista dan Astohar (2012) bahwa struktur modal (DER) berpengaruh negatif terhadap return saham perusahaan. Semakin besar nilai DER, maka risiko gagal bayar yang dihadapi oleh perusahaan akan semakin besar. Selain itu, semakin tinggi DER perusahaan juga harus membayar biaya bunga yang tinggi. Apabila hal tersebut terjadi, maka dapat mengakibatkan penurunan pembayaran dividen karena dianggap sebagai informasi yang buruk oleh investor, sehingga permintaan terhadap saham perusahaan akan mengalami penurunan yang berakibat pada penurunan harga saham. Kondisi tersebut menandakan saham perusahaan kurang diminati yang secara langsung akan menurunkan tingkat return saham perusahaan.

\section{KESIMPULAN}

Setelah mengkaji hasil penelitian ini, maka diperoleh beberapa implikasi bagi pihak manajemen dan investor. Pertama, struktur modal yang terlalu tinggi, berarti terlalu banyaknya proporsi modal yang berasal dari luar atau hutang yang digunakan akan berdampak pada meningkatnya biaya modal yang ditanggung perusahaan. Di samping itu, dengan terlalu kecilnya struktur modal, seringkali berakibat pada hilangnya peluang pasar yang dapat dicapai, karena perusahaan tidak mampu memenuhi permintaan pasar sebagai akibat kekurangan modal untuk meningkatkan produksinya. Kedua, hasil penelitian ini memperlihatkan bahwa ROA, current ratio, cash holding, non-debt tax shield, dan asset growth secara bersama-sama berpengaruh terhadap struktur modal. Hasil tersebut dapat dijadikan salah satu pertimbangan bagi manajemen perusahaan dalam menentukan kebijakan struktur modal untuk meningkatkan kinerja perusahaan, sehingga mampu menjaga kepercayaan investor untuk berinvestasi di perusahaan. Ketiga, investor dalam menggunakan kebijakan investasinya agar mempertimbangkan berbagai hal terkait dengan semua informasi relevan yang tersedia di pasar modal baik melalui laporan keuangan yang dipublikasikan perusahaan atau informasi lain yang dirasa relevan, termasuk dengan mengetahui bagaimanakah struktur pendanaan dari perusahaan apakah sudah optimal atau belum, karena perusahaan dengan proporsi struktur modal yang optimal dapat meningkatkan tingkat pengembalian yang akan didapatkan. Penelitian selanjutnya diharapkan dapat menambahkan variabel-variabel lain yang dapat mempengaruhi struktur modal dan return saham. Selain itu, diharapkan peneliti selanjutnya dapat menambah jumlah sampel dan periode penelitian untuk mendapatkan hasil yang lebih baik.

\section{DAFTAR PUSTAKA}

Adhegaonkar, V. dan Indi, R.M. (2012). Determinants of capital structure: A case of Indian chemical industry. International Journal of Marketing and Technology, 2(10). 
Arista, D. dan Astohar. (2012). Analisis faktor-faktor yang mempengaruhi return saham (kasus pada perusahaan manufaktur yang go public di BEI periode tahun 2005-2009). Jurnal Ilmu Manajemen dan Akuntansi Terapan, 3(1).

Brigham, E.F. dan Houston, J.F. (2011). Dasar-dasar manajemen keuangan essentials of financial management P(buku 2, edisi kesebelas). Jakarta: Salemba Empat.

Fahmi, I. (2014). Analisis laporan keuangan. Bandung: Alfabeta.

Febriyani dan Srimindarti. (2010). Faktor-faktor yang mempengaruhi struktur modal pada perusahaan-perusahaan LQ-45 di Bursa Efek Indonesia tahun 2006-2008. Dinamika Keuangan dan Perbankan, 2(2), 138-159.

Ferdiansya, M.S. dan Isnurhadi. (2013). Faktor-faktor yang mempengaruhi struktur modal pada perusahaan pertambangan yang terdaftar di Bursa Efek Indonesia. Jurnal Manajemen \& Bisnis Sriwijaya, 11(2).

Hanafi, M.M. dan Halim, A. (2012). Analisis laporan keuangan (edisi keempat). Yogyakarta: UPP STIM YKPN.

Hasni, Y. (2013). Pengaruh tingkat profitabilitas, struktur asset, dan growth opportunity terhadap struktur modal pada perusahaan manufaktur yang telah go public di Bursa Efek Indonesia. Jurnal manajemen \& Bisnis Sriwijaya, 13(4), 545558.

Jogiyanto, H.M. (2010). Teori portofolio dan analisis investasi (edisi ketujuh). Yogyakarta: BPFE.

Khariry, M. dan Yusniar, M.W. (2016). Faktor-faktor yang mempengaruhi struktur modal: Studi kasus pada perusahaan manufaktur yang terdaftar di Bursa Efek Indonesia periode 2011-2014. Jurnal Wawasan Manajemen, 4(2).

Krisnanda, P.H. dan Wiksuana, I.G.B. (2015). Pengaruh ukuran perusahaan, pertumbuhan penjualan, dan non-debt tax shield terhadap struktur modal pada perusahaan telekomunikasi di Bursa Efek Indonesia. E-Jurnal Manajemen Unud, 4(5).

Kristian, N. dan Khuzaini. (2014). Pengaruh likuiditas dan profitabilitas terhadap struktur modal dan rasio aktivitas sebagai intervening. Jurnal Ilmu \& Riset Manajemen, 3(12).

Margaretha, F. dan Ramadhan, A.R. (2010). Faktor-faktor yang mempengaruhi struktur modal pada industri manufaktur di Bursa Efek Indonesia. Jurnal Bisnis dan Akuntansi, 12(2), 119-130.

Martono dan Harjito, A. (2010). Manajemen keuangan (edisi keempat). Yogyakarta: Ekonisia.

Mohammadi et al. (2012). The effect of cash holding on income smoothing. Journal of Contemporary Research in Business, 4(2).

Najmudin. (2011). Manajemen keuangan: Keputusan investasi dan pendanaan jangka panjang. Purwokerto: UPT Percetakan dan Penerbitan Unsoed.

Nurita, D. dan Mawardi, W. (2012). Analisis pengaruh profitabilitas, firm size, non debt tax shield, dividen payout ratiodan likuiditas terhadap struktur modal (pada perusahaan manufaktur yang terdaftar di Bursa Efek Indonesia periode tahun 2007-2010). Diponegoro University Institutional Repository.

Nurmadi, R. (2013). Analisis faktor-faktor yang mempengaruhi struktur modal perusahaan manufaktur. Jurnal Keuangan dan Bisnis, 5(2).

Prasojo, S. (2013). Faktor-faktor yang berpengaruh terhadap struktur modal pada perusahaan manufaktur yang terdaftar di Bursa Efek Indonesia (BEI) tahun 2010-2012. Jurnal Universitas Dian Nuswantoro Semarang.

Ramlall, I. (2009). Determinants of capital structure among non-quoted mauritian firms under specificity of leverage: Looking for a modified pecking order theory. International Research Journal of Finance and Economics, 31, 83-92.

Riyanto, B. (2008). Dasar-dasar pembelanjaan perusahaan. Yogyakarta: Gajahmada.

Samsul, M. (2008). Pasar modal dan manajemen portofolio. Jakarta: Erlangga.

Shelly. (2016). Determinan struktur modal dan pengaruhnya terhadap nilai perusahaan perusahaan wholesale and retail terdaftar pada BEI 2008-2012. Media Studi Ekonomi, 19(1).

Stella. (2015). Pengaruh profitabilitas, non-debt tax shield dan karakteristik perusahaan terhadap struktur modal. Jurnal Bisnis dan Akuntansi, 17(1), 96-101.

Sugiyono. (2012). Statistika untuk penelitian. Bandung: Alfabeta.

Sulistyowati, W.A. (2009). Penentuan kebijakan struktur modal pada perusahaan manufaktur di Bursa Efek Indonesia. EPrints Universitas Diponegoro.

Suliyanto. (2011). Ekonometrika terapan: Teori dan aplikasi dengan SPSS. Yogyakarta: Andi Offset.

Suwitho dan Zuhro, F. (2016). Pengaruh ukuran perusahaan, pertumbuhan aset, dan profitabilitas terhadap struktur modal. Jurnal Ilmu dan Riset Manajemen, 5(5).

Tandelilin, E. (2010). Portofolio dan investasi teori dan aplikasi (edisi pertama). Yogyakarta: Kanisius.

Van Horne, J.C. dan Wachowics, J.M. (2009). Prinsip-prinsip manajemen keuangan. Jakarta: Salemba Empat.

Widayanti, L.P., Triaryati, N., dan Abundanti, N.. (2016). Pengaruh profitabilitas, tingkat pertumbuhan perusahaan, likuiditas, dan pajak terhadap struktur modal pada sektor pariwisata. E-Jurnal Manajemen Universitas Udayana, 5(6). 
Yuniati, F.R. dan Pangestuti, I.R. (2010). Analisis faktor-faktor yang mempengaruhi struktur modal pada perusahaan manufaktur di Bursa Efek Indonesia tahun 2004-2009. Jurnal Universitas Diponegoro Semarang.

Yushinta, P. dan Erni, S. (2010). Analisis faktor-faktor yang mempengaruhi struktur modal (studi empiris pada perusahaan manufaktur di Bursa Efek Indonesia). Jurnal Akuntansi dan Investasi, 11(2), 179-188. 